\title{
Correction to: A Relative Cost of Control Analysis of Once-Weekly Semaglutide Versus Exenatide Extended-Release and Dulaglutide for Bringing Patients to HbA1c and Weight Loss Treatment Targets in the USA
}

Pierre Johansen $\cdot$ Barnaby Hunt (D) - Neeraj N. Iyer $\cdot$ Tam Dang-Tan

Richard F. Pollock

Published online: April 12, 2019

(c) The Author(s) 2019

Correction to: Adv Ther

https://doi.org/10.1007/s12325-019-00915-8

The article "A Relative Cost of Control Analysis of Once-Weekly Semaglutide Versus Exenatide Extended-Release and Dulaglutide for Bringing Patients to HbA1c and Weight Loss Treatment Targets in the USA", written by Pierre Johansen, Barnaby Hunt, Neeraj N. Iyer, Tam Dang-Tan, Richard F. Pollock was originally published electronically on the publisher's internet portal (currently SpringerLink) on November 27, 2018 without Open Access.

The article has now been made Open Access. The copyright of the article changed to (c) The

The original article can be found online at https://doi. org/10.1007/s12325-019-00915-8.

P. Johansen

Novo Nordisk A/S, Søborg, Denmark

B. Hunt $(\bowtie) \cdot$ R. F. Pollock

Ossian Health Economics and Communications

$\mathrm{GmbH}$, Basel, Switzerland

e-mail: hunt@ossianconsulting.com

N. N. Iyer · T. Dang-Tan

Novo Nordisk Inc, Plainsboro, USA

Author(s) 2018 and the article is forthwith distributed under the terms of the Creative Commons Attribution-NonCommercial 4.0 International License (http://creativecommons. org/licenses/by-nc/4.0/), which permits any non-commercial use, distribution, and reproduction in any medium, provided you give appropriate credit to the original author(s) and the source, provide a link to the Creative Commons license, and Indicate if changes were made.

The original article has been updated.

Open Access. This article is distributed under the terms of the Creative Commons Attribution-NonCommercial 4.0 International License (http://creativecommons.org/licenses/ by-nc/4.0/), which permits any noncommercial use, distribution, and reproduction in any medium, provided you give appropriate credit to the original author(s) and the source, provide a link to the Creative Commons license, and indicate if changes were made. 